\title{
Selenium and the risk of cancers of the colon, pancreas and stomach
}

\author{
Marcin Lener ${ }^{1 *}$, Anna Wiechowska-Kozłowska², Józef Kładny³ ${ }^{3}$ Magdalena Muszyńska', Grzegorz Sukiennicki', \\ Lidia Kubera-Nowakowska', Jan Lubiński
}

From Annual Conference on Hereditary Cancers 2011

Szczecin, Poland. 17-18 November 2011

\section{Introduction}

Research suggests that selenium may influence the behavior of the cancer risk in two ways. As an antioxidant, selenium helps to protect the body against free radicals. Selenium may also prevent or slow tumor growth, as some breakdown products of selenium can inhibit tumor growth by enhancing immune cell activity and inhibition of tumor blood vessel development.

\section{Aim}

The aim of this study was to determine the level of selenium in blood serum as a potential marker of risk for cancers of the colon, stomach or pancreas.

\section{Material and methods}

The research material was a total of 94 samples of blood serum from people with cancer, diagnosed and confirmed in one of the organs: colon (55 cases), pancreas (30 cases) or stomach (9 cases) and 94 samples of blood serum derived from healthy individuals which paired control group. The criteria adopted for pairing included: gender, year of birth ( $+/-3$ years), history of the occurrence of cancers in the family among first degree relatives and smoking status expressed in pack-years.

Selenium concentration in blood plasma was determined using graphite furnace atomic absorption spectrometry (GFAAS). The measurement accuracy was $+/-5 \%$ $\mu \mathrm{g} \mathrm{Se} / \mathrm{l}$.

\section{Results}

Association between Se concentration and frequency of cancers in quartiles are presented in table 1. Statistical analyses are summarized in table 2 .

\section{Conclusions}

The obtained results suggest that low levels of selenium in the body may correlate with an increased risk of pancreatic cancer, colon or stomach, and thus constitute

Table 1 Association between Se plasma concentration and risk of cancers analyzed.

\begin{tabular}{cccc}
\hline Cancer site & Quartile & Se concentration range $(\mu \mathrm{g} / \mathrm{l})$ & Cases [\% - no] \\
\hline Pancreas & I & $25,69-50,09$ & $100 \%(15 / 15)$ \\
\hline & $\|$ & $50,72-65,58$ & $60 \%(9 / 15)$ \\
\hline III & $66,34-73,30$ & $40 \%(6 / 15)$ \\
\hline & IV & $74,07-113,89$ & $-(0 / 15)$ \\
\hline & I & $15,92-55,25$ & $87,5 \%(28 / 32)$ \\
\hline & $\|$ & $56,08-67,05$ & $59,37 \%(19 / 32)$ \\
\hline III & $67,22-75,96$ & $25 \%(8 / 32)$ \\
\hline
\end{tabular}

\footnotetext{
* Correspondence: marcinlener@poczta.onet.pl

'Department of Genetics and Pathology, Pomeranian Medical University in

Szczecin, Poland

Full list of author information is available at the end of the article
}

\section{() Biomed Central}

(c) 2012 Lener et al; licensee BioMed Central Ltd. This is an Open Access article distributed under the terms of the Creative Commons Attribution License (http://creativecommons.org/licenses/by/2.0), which permits unrestricted use, distribution, and reproduction in any medium, provided the original work is properly cited. 
Tab.2 Results of statistical analyses of cancer site depending on Se concentration.

\begin{tabular}{|c|c|c|c|c|c|c|}
\hline \multirow[t]{2}{*}{ Cancer site } & \multirow[t]{2}{*}{ Quartiles compared } & \multirow[t]{2}{*}{ Se concentration range $(\mu \mathrm{g} / \mathrm{l})$} & \multirow[t]{2}{*}{ Cases/controls in compared groups } & \multicolumn{3}{|c|}{ Fisher's exact test } \\
\hline & & & & $P$ & OR & $\mathrm{Cl}$ \\
\hline \multirow[t]{3}{*}{ Pancreas } & | vs || & $25,69-50,09$ vs $50,72-65,58$ & $15 / 0$ vs $9 / 6$ & 0,017 & 21,2 & $1,07-421,11$ \\
\hline & | vs I|| & $25,69-50,09$ vs $66,34-73,30$ & $15 / 0$ vs $6 / 9$ & 0,0007 & 45,3 & $2,2-899,53$ \\
\hline & I vs IV & $25,69-50,09$ vs $74,07-113,89$ & $15 / 0$ vs $0 / 15$ & $<0,0001$ & 961 & $7,9-51,617$ \\
\hline \multirow[t]{3}{*}{ Colorectal and stomach } & | vs || & $15,92-55,25$ vs $56,08-67,05$ & $(5)^{*} 28 / 4$ vs $(3)^{*} 19 / 13$ & 0,0219 & 4,79 & $1,35-16,94$ \\
\hline & | vs III & $15,92-55,25$ vs $67,22-75,96$ & $(5)^{*} 28 / 4$ vs $(0)^{*} 8 / 24$ & $<0,0001$ & 21 & $5,6-78,5$ \\
\hline & I vs IV & $15,92-55,25$ vs $76,45-103,36$ & $(5) * 28 / 4$ vs $(1)^{*} 9 / 23$ & $<0,0001$ & 17,9 & $4,8-65,7$ \\
\hline
\end{tabular}

*stomach cancer cases

one of the markers of risk for cancers of such sites. Research requires the extension to a larger number of samples including tumor size, and performance analysis for selenoprotein genes.

Prospective studies can elucidate:

a) the use of selenium measurements as markers of risk of above cancers;

b) possibility of lowering risk of the cancers of the colon, pancreas and stomach by supplementation of diet with selenium.

\section{Author details}

${ }^{1}$ Department of Genetics and Pathology, Pomeranian Medical University in Szczecin, Poland. 'Laboratory of Endoscopy, Division of Health Care Ministry of Internal Affairs and Administration in Szczecin, Poland. ${ }^{3}$ Department of General and Oncological Surgery, Pomeranian Medical University, Szczecin, Poland.

Published: 20 April 2012

\section{Submit your next manuscript to BioMed Central} and take full advantage of:

- Convenient online submission

- Thorough peer review

- No space constraints or color figure charges

- Immediate publication on acceptance

- Inclusion in PubMed, CAS, Scopus and Google Scholar

- Research which is freely available for redistribution 